\title{
Jerzy Lewandowski, W nadziei jesteśmy odkupieni. Komentarz do encykliki Benedykta XVI „Spe salvi”, Wydawnictwo Archidiecezji Warszawskiej, Warszawa 2008, s. 209
}

Nauczanie Kościoła, tak dogmatyczne jak i etyczno-moralne, na przestrzeni wieków, przybierało różne formy. To zaś rzutowało na jego postrzeganie życiowe oraz moc zobowiązującą dla Kościoła, a zwłaszcza poszczególnych ochrzczonych. Wnikanie w ewangeliczne orędzie oraz przedstawianie prawd wiary stanowi ważny element całego przepowiadania, zwłaszcza papieża i Magisterium Kościoła. W tym kontekście jedną ze szczególnie ważnych form jest encyklika, uroczysty list papieski.

Papież Benedykt XVI jako pierwszą opublikował encyklikę Deus caritas est. Tym samym jakby zapoczątkował, tak się wówczas spodziewano, pewien cykl poświęcony cnotom teologalnym. Kolejna encyklika nosi tytuł: Spe salvi i jakby potwierdza spodziewany szereg. Wydaje się także, iż automatycznie określa się kolejne oczekiwanie, które poświęcone będzie wierze.

W przybliżeniu treści ostatniej encykliki, obok sięgania do oryginału, szczególnie ważne są komentarze. W języku polskim ukazał się pierwszy z nich pióra ks. prof. dra hab. Jerzego Lewandowskiego z Uniwersytetu Kardynała Stefana Wyszyńskiego w Warszawie. Autor jest wybitnym dogmatykiem, a zwłaszcza znawcą nauczania kard. S. Wyszyńskiego, Prymasa Polski i współczesnej problematyki teologicznej. Wykłada także w Uniwersytecie Muzycznym im. Fryderyka Chopina w Warszawie.

Publikację otwiera krótkie wprowadzenie (s. 3-5). Następnie podzielona ona została na cztery bloki. Noszą one w kolejności następujące tytuły: 1. Nadzieja budulcem ludzkiej egzystencji (s. 5-52); 2. Wiara źródłem nadziei na życie szczęśliwe (s. 52-105); 3. Nadzieja fundamentem przestrzeni wolności (s. 106-157); 4. Nadzieja na życie wieczne (s. 157-208). Całość zamyka schematyczny spis treści (s. 209).

Tytuły te są znakomitym wskazaniem podejmowanych treści. Wyakcentowano zasadnicze idee, które pozwalają już na wstępie lektury dostrzec zasadniczy nurt papieskiej refleksji. To także ukazuje specyfikę pogłębionej analizy teologalnej cnoty nadziei.

Z kart prezentowanej publikacji tchnie duża świeżość pochylenia się nad kolejną encykliką Benedykta XVI. Czuć tutaj, przynajmniej w pewnych fragmentach, echo pierwszej, tj. Deus caritas est. Zatem to pewna kontynuacja, pogłębiająca wiele szczegółowych zagadnień. 
Przybliżenie nadziei, tej w tradycji wskazywanej jako druga cnota teologalna, staje się jeszcze bardziej aktualne w kontekście dobrze rozeznanej teraźniejszości. Cnota ta wybrzmiewa szczególnie twórczo i praktyczne w życiu nie tylko człowieka wiary. Jest ona postrzegalna także jako cnota naturalna, a więc wpisana w ludzką naturę i kulturę.

Ojciec św. Benedykt XVI szczególnie podkreśla właśnie odniesie zwrotne nadziei i kultury. Niemniej jednak jej osią i centrum zawsze pozostaje Jezus Chrystus. Tylko w Nim może ona być poprawnie rozeznawana, a następnie stanowić twórczy elementem ludzkiego oraz chrześcijańskiego pielgrzymowania na ziemi, zwłaszcza we wspólnocie ludu Bożego Nowego Przymierza. Dlatego staje ona niezwykle realistycznie.

Ważnym elementem ukazującym encyklikę jest wskazanie na jego personalizm. Może wybrzmiewa to zbyt mało wyraźnie, zwłaszcza w płaszczyźnie terminologicznej. Koncentracja na osobie pozwala na doskonalsze i bardziej pogłębione rozeznanie samej nadziei. Jawi się ona jako bardziej twórcza i dynamiczna.

W generalnym spojrzeniu nie tylko na nadzieję, ale szerzej na ogólne współczesne procesy cywilizacyjne i kulturowe, słuszna jest uwaga autora: „Światu, który się rozpadł kulturowo, podarowano wiarę, nadzieję i miłość, które od dwu tysięcy lat podtrzymywały kulturę, zwłaszcza europejską, w jej powinnościach afirmacji ludzkiego życia, jego godności i solidarności. Dekadentyzm współczesności przypomina w pewnej mierze ten moment rozwoju cywilizacji. Papież Benedykt XVI zwraca uwagę na współczesną sytuację która naznaczona jest diamentem kulturowym i cywilizacyjnym. W tym kontekście pojawia się nowa encyklika Benedykta XVI, Spe salvi - W nadziei jesteśmy zbawieni» (Vatican 2007)” (s. 4-5).

Dobrym zabiegiem jest, że autor przywołuje odniesienia do samej encykliki, a także zwłaszcza te, które występują w samym jej tekście. Ich wskazanie pozwala doświadczyć inspiracji myślowych, także pozachrześcijańskich, które stanowiły dla papieża element współtworzenia tego dokumentu.

Wskazany tytuł encykliki szczególnie dynamicznie współbrzmi z całym nauczaniem papieskim. Przepowiadanie Benedykta XVI tworzy szczególną mozaikę teologiczną, która pozwala wiele prawd wiary postrzegać jako konkretny realizm życia. Forma ich podania sprawia, że jawią się one w formie bardziej komunikatywnej i czytelnej, także dla współczesnego odbiorcy. Nawet dla niewierzących stają się pewnymi pytaniami czy egzystencjalnym oglądem człowieka.

Warszawski uczony jawi się jako dobry komentator encykliki Spe salvi. Jest to dyskretne towarzyszenie przemawiającemu papieżowi. Zatem zasadnicze treści prezentowanej książki to myśli i przepowiadanie papieskie. Stał się zatem sługą, jako przystoi teologowi, zwłaszcza kierującemu Katedrą Teologii Współczesnej wobec papieskiego nauczania, czyniąc je bardziej komunikatywnym i przystępnym. 